\title{
EFFECTS OF FOLIAR FEEDING UNDER DIFFERENT SOIL FERTILIZATION CONDITIONS ON THE YIELD STRUCTURE AND QUALITY OF WINTER WHEAT (Triticum aestivum L.)
}

\author{
Stanisław Chwil \\ Department of Agricultural and Environmental Chemistry, University of Life Sciences in Lublin \\ Akademicka 15, 20-950 Lublin, Poland \\ e-mail: stanislaw.chwil@up.lublin.pl
}

Received: 28.08.2014

\begin{abstract}
The aim of the study was to analyse foliar feeding of winter wheat cv. 'Kobra' in combination with different soil fertilization treatments with calcium and magnesium compounds. The foliar fertilizers INSOL PK $+5 \%$ urea solution and EKOSOL U were applied 3 times during the during the growing season in four soil fertilization treatments: control without fertilization, $\mathrm{NPK}, \mathrm{NPK}+\mathrm{MgSO}_{4} \times 7 \mathrm{H}_{2} \mathrm{O}$, and $\mathrm{NPK}+\mathrm{CaO}+\mathrm{MgO}$. The investigations involved a 3 -year field experiment established on medium soil with a $\mathrm{pH}$ of 4.2 in 1 mole $\mathrm{KCl} \times \mathrm{dm}^{-3}$ and with the granulometric composition of clayey silt. The soil was characterised by a low content of available phosphorus and potassium as well as a very low content of sulphur and magnesium. The foliar fertilizers applied and the soil fertilization treatments had a varied effect on the yield parameters, the macronutrient content in grain and straw, and the content and quality of gluten. Among the soil fertilization treatments, the best production results and quality parameters of winter wheat were obtained after the application of the dose with magnesium lime. The foliar fertilizers had a greater impact on yield and gluten content than on the mineral composition of winter wheat grain and straw.
\end{abstract}

Key words: Triticum aestivum, foliar feeding, yield components, macronutrients, crude protein, gluten

\section{INTRODUCTION}

The dynamic growth of the Earth's population requires us to continuously increase the production of plants intended for human consumption or animal fodder in order to meet the food demand. Cereals are a primary raw material for production of consumer goods, with the greatest importance attached to wheat, rice, and maize. Given the increasing urbanisation, higher crop yields are mainly achieved by improving productivity per unit area rather than by increasing the crop acreage.
Winter wheat is a plant with specific habitat requirements. The cultivation of wheat aimed at improving the productivity and quality of crop yields leads to the introduction of cultivars with higher nutrient demand into farming. A high rate of fertilization causes an environmental burden associated with unused nutrients $[1,2]$ and therefore, apart from soil fertilization, foliar fertilizers containing mainly $\mathrm{N}, \mathrm{Mg}$, and micronutrients are used in intensive farming [3-5]. The study showed greater effectiveness of foliar feeding compared to soil fertilization [6-8]. Foliar feeding allows fertilizer consumption to be reduced by improving the economic indicators of soil fertilization [9]. Combined application of foliar fertilizers with plant protection treatments lowers production costs and simultaneously improves the effectiveness of pesticides so that they can be used at a minimal dose $[10,11]$.

The aim of the study was to determine the effect of foliar fertilization combined with soil fertilization treatments with calcium and magnesium compounds on yield and basic quality parameters of winter wheat.

\section{MATERIALS AND METHODS}

A three-year field experiment was established using a randomised block design in Rudnik $\left(50^{\circ} 53^{\prime} 23.99^{\prime \prime} \mathrm{N}, 22^{\circ} 57^{\prime} 59.89^{\prime} \mathrm{E}\right)$ on clayey silt with a $\mathrm{pH}$ of 4.2 in 1 mole $\mathrm{KCl} \times \mathrm{dm}^{-3}$, characterised by a low content of available phosphorus and potassium as well as a very low content of sulphur and magnesium. The climatic parameters during the study period compared with the long-term means are presented in Figure 1. The experimental design consisted of 3 treatments receiving foliar fertilization (1. control 
treatment/spraying with water, 2. INSOL PK $+5 \%$ urea solution, 3. EKOSOL U) and 4 treatments of soil fertilization (1. control/no fertilization, 2. NPK, 3. $\left.\mathrm{NPK}+\mathrm{MgSO}_{4} \times 7 \mathrm{H}_{2} \mathrm{O}, 4 . \mathrm{NPK}+\mathrm{CaO}+\mathrm{MgO}\right)$, in 3 replicates.

Immediately after harvest of the previous crop, magnesium oxide lime was applied to randomly chosen $48 \mathrm{~m}^{2}$ plots according to single hydrolytic acidity. Mineral fertilization with Amofoska 4-16-18 and 4.5S as well as ammonium nitrate were applied at the rates of $102 \mathrm{~kg}$ $\mathrm{N} \times \mathrm{ha}^{-1}, 28 \mathrm{~kg} \times \mathrm{P} \mathrm{ha}^{-1}$, and $61 \mathrm{~kg} \mathrm{~K} \times \mathrm{ha}^{-1}$. Additionally, each year before sowing the winter wheat (Triticum aetivum L.) cultivar 'Kobra', magnesium sulphate at a dose of $19 \mathrm{~kg} \mathrm{Mg} \times$ ha $^{-1}$ was applied to randomly chosen plots. In the plots treated with INSOL PK with the addition of urea, the nitrogen dose was reduced by $20.7 \mathrm{~kg}$ $\mathrm{N}$ ha ${ }^{-1}$, since that amount was supplied through foliar feeding with the $5 \%$ urea solution spray liquid.

Foliar feeding was used 3 times during the growing season at the stages of tillering, stem elongation, and ear emergence. The foliar fertilizers were used in each soil fertilization treatment at the following doses: INSOL PK $-6 \mathrm{dm}^{3} \cdot 300 \mathrm{dm}^{-3} \times \mathrm{ha}^{-1}$ and EKOSOL U $-2 \mathrm{dm}^{3} \times 300 \mathrm{dm}^{-3} \times \mathrm{ha}^{-1}$. INSOL PK contained (\%): $\mathrm{P}-4.4$ and $\mathrm{K}-15.8$, whereas EKOSOL $\mathrm{U}$ contained (\%): $\mathrm{N}-15 ; \mathrm{P}-2.2 ; \mathrm{K}-2.7 ; \mathrm{Na}-0.15$; $\mathrm{B}-0.01 ; \mathrm{Cu}-0.012 ; \mathrm{Fe}-0.012 ; \mathrm{Mn}-0.017$; $\mathrm{Mo}-$ 0.002 ; and $\mathrm{Zn}-0.1$.
The Triticum aetivum was harvested at the full maturity stage and samples were taken from $1 \mathrm{~m}^{2}$ in 3 replicates. The grain and straw yields as well as the major yield components, i.e. grain weight per ear, number of ears $/ \mathrm{m}^{2}$, number of grains per ear, and 1000-grain weight, were assessed in the samples.

After mineralization in concentrated sulphuric acid with the addition of hydrogen peroxide, the grain and straw were assayed for total $\mathrm{N}$ with the Kjeldahl method; $\mathrm{K}, \mathrm{Ca}$, and $\mathrm{Mg}$ with the AAS method using a Hitachi Z-8200 polarized Zeeman atomic absorption spectrophotometer; and $\mathrm{P}$ by the vanadium-molybdate colorimetric method using a Cecil 2011 colorimeter. Total sulphur was determined according to B u t t e r s $\mathrm{C}$ hen er y [12]. The macronutrient removal was calculated as the sum of a nutrient in the primary yield and in the straw based on the nutrient content in the organs. The qualitative assessment of the yield comprised $\mathrm{K}:(\mathrm{Ca}+\mathrm{Mg})$ equivalent ratios, $\mathrm{N}: \mathrm{S}$ mass ratios, total protein content ( $\mathrm{N} \times 5.7)$, protein yield, and gluten content and its weakening according to the Polish standard PN-ISO-74041.

The results obtained were statistically analysed by analysis of variance and presented as means from the 3-year study period (1999-2001). The significance test was conducted using T-Tukey's multiple confidence intervals at a significance level of 0.05 .

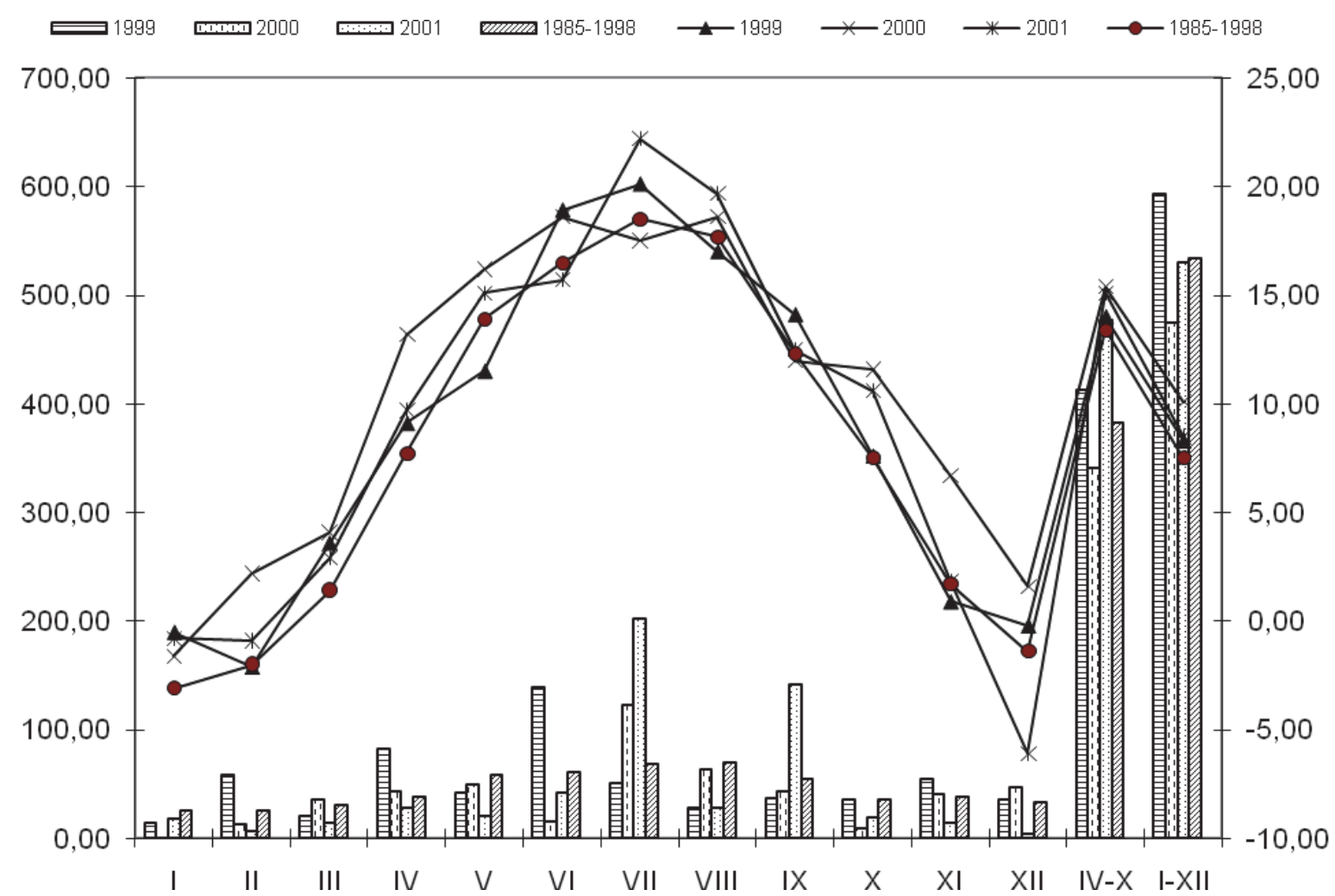

Fig. 1. Climatic conditions in the study period 


\section{RESULTS}

\section{Yield potential}

The soil fertilization treatments applied in the experiment caused differences in the grain and straw yields and in all the yield components. Grain and straw yields as well as 1000-grain weight, number of ears, and number of grains per ear exhibited the highest values after the application of NPK with $\mathrm{CaO}+\mathrm{MgO}$ fertilization. In turn, the magnesium sulphate $\mathrm{MgSO}_{4}$ addition produced the highest increase in the number of spikelets per ear (Table 1). The foliar fertilizers increased the yield and yield components in comparison with the control with the exception of the number of grains per ear. Among the foliar fertilizers applied, INSOL PK exerted a better effect on the winter wheat yield than EKOSOL U. The interaction between soil fertilization and foliar feeding had a significant impact only on the number of grains per ear.

\section{The mineral composition of winter wheat}

The content of macronutrients in winter wheat grain determined in the experiment is presented in Table 2. Both soil fertilization and foliar feeding changed the macronutrient content in the grain. Fertilization with the addition of the $\mathrm{CaO}+\mathrm{MgO}$ doses significantly increased the contents of nitrogen, potassium, calcium, magnesium, and sulphur in comparison with the other soil fertilization treatments. The introduction of $\mathrm{MgSO}_{4}$ to the fertilization treatment resulted in the highest $\mathrm{S}$ content but did not increase the magnesium content.

Deacidification of the soil also significantly increased the content of nitrogen, phosphorus, potassium, calcium, and magnesium in winter wheat straw in comparison with the control or the basic fertilization treatment (Table 3). Fertilization with the addition of the $\mathrm{MgSO}_{4}$ dose significantly increased the sulphur content in straw and reduced the phosphorus content in comparison with the other treatments.

Foliar feeding had a significantly lower effect on the mineral composition than soil fertilization. Compared with the control treatment, the foliar fertilizers caused a significant increase in the content of nitrogen, calcium, and magnesium, while EKOSOL $\mathrm{U}$ additionally increased the sulphur content in winter wheat grain (Table 3). The foliar fertilizers applied significantly increased the content of nitrogen, phosphorus, and magnesium in straw, whereas INSOL PK increased the calcium content.
In the control treatment, which did not involve soil fertilization, the lowest values of the nutrient removal differed significantly from those obtained in the other fertilization treatments (Table 4).

The NPK $+\mathrm{CaO}+\mathrm{MgO}$ treatment was characterised by the greatest removal of the analysed macronutrients; only in the case of sulphur the removal of this element was higher after the application of NPK $+\mathrm{MgSO}_{4}$. The interaction between foliar feeding and soil fertilization had a significant impact on the removal of all the nutrients analysed.

\section{Yield quality parameters}

In the experiment, both soil fertilization and foliar feeding hada similar effect on the protein content in winter wheat grain, compared with the control (Table 5). No significant differences were found between the foliar fertilizers applied and the different treatments of soil fertilization. The soil fertilization exerted a more beneficial effect on the protein yield than that of the foliar fertilizers. All soil fertilization treatments increased the protein yield in relation to the control; furthermore, a significantly higher protein yield was obtained in the $\mathrm{NPK}+\mathrm{CaO}+\mathrm{MgO}$ treatment than in the other soil fertilization treatments (Table 5). The content of gluten depended on the soil fertilization treatments to a greater degree than on the foliar fertilizers applied, as indicated by the significant differences found between each fertilization treatment. Similar doses of INSOL PK and EKOSOL U increased the value of this parameter in relation to the control. Gluten weakening, whose value varied depending on soil fertilization and foliar fertilizers applied, is an important indicator of gluten quality. Generally, a higher content of gluten was accompanied by higher weakening values (Table 5).

The factors applied in the experiment resulted in a similar $\mathrm{K}:(\mathrm{Ca}+\mathrm{Mg})$ ratio in winter wheat grain and straw at a level of $0.7-1.0: 1$, and in a clear narrowing trend was found in the values under the application of the foliar fertilizers (Table 6). The use of the foliar fertilizers increased the $\mathrm{N}: \mathrm{S}$ ratio in the grain. In turn, among the soil fertilization treatments applied, only $\mathrm{NPK}+\mathrm{MgSO}_{4}$ significantly reduced the $\mathrm{N}: \mathrm{S}$ ratio in winter wheat grain and straw, whereas the foliar fertilizers increased the ratio values, with the exception of EKOSOL $U$ which decreased the value of this parameter (Table 6). 
Table 1

Grain and straw yield as well as the yield structure of foliar fertilized winter wheat under different soil fertilization conditions

\begin{tabular}{|c|c|c|c|c|c|c|c|}
\hline \multirow{2}{*}{$\begin{array}{l}\text { Foliar } \\
\text { fertilizer } \\
\text { (A) }\end{array}$} & \multirow{2}{*}{$\begin{array}{c}\text { Soil } \\
\text { fertilization } \\
\text { (B) }\end{array}$} & \multirow{2}{*}{$\begin{array}{c}\text { Grain yield } \\
\mathrm{t} \mathrm{ha}^{-1}\end{array}$} & \multirow{2}{*}{$\begin{array}{c}\text { Straw yield } \\
\mathrm{t} \mathrm{ha}^{-1}\end{array}$} & \multirow{2}{*}{$\begin{array}{c}\text { Thousand } \\
\text { grain weight } \\
{[\mathrm{g}]}\end{array}$} & \multirow{2}{*}{$\begin{array}{c}\begin{array}{c}\text { Number } \\
\text { of ears }\end{array} \\
\text { [pcs] (per } \\
\text { square metre) }\end{array}$} & \multirow{2}{*}{$\begin{array}{c}\begin{array}{c}\text { Number of } \\
\text { spikelets } \\
\text { per ear }\end{array} \\
\text { [pcs] }\end{array}$} & \multirow{2}{*}{$\begin{array}{c}\begin{array}{c}\text { Number of } \\
\text { grains } \\
\text { per ear }\end{array} \\
\text { [pcs] }\end{array}$} \\
\hline & & & & & & & \\
\hline WATER & & 2.5 & 3.5 & 34.5 & 319.7 & 13.3 & 25.6 \\
\hline INSOL PK & Control & 3.0 & 4.8 & 35.9 & 377.6 & 14.5 & 26.0 \\
\hline EKOSOL U & & 2.7 & 4.0 & 35.9 & 338.3 & 14.1 & 25.5 \\
\hline WATER & & 4.0 & 5.7 & 37.5 & 414.3 & 14.0 & 28.9 \\
\hline INSOL PK & NPK & 4.4 & 6.3 & 39.1 & 417.3 & 14.6 & 29.9 \\
\hline EKOSOL U & & 4.2 & 5.8 & 38.1 & 438.2 & 15.1 & 29.5 \\
\hline WATER & & 4.3 & 5.7 & 37.8 & 422.5 & 14.3 & 29.4 \\
\hline INSOL PK & $\mathrm{NPK}+\mathrm{MgSO}_{4}$ & 4.6 & 6.5 & 39.8 & 426.5 & 15.3 & 30.7 \\
\hline EKOSOL U & & 4.5 & 5.7 & 39.1 & 424.7 & 15.2 & 30.6 \\
\hline WATER & & 4.6 & 5.7 & 39.4 & 432.9 & 14.3 & 32.1 \\
\hline INSOL PK & $\mathrm{NPK}+\mathrm{CaO}+\mathrm{MgO}$ & 5.2 & 7.0 & 41.7 & 471.8 & 14.9 & 32.4 \\
\hline EKOSOL U & & 4.9 & 6.4 & 40.0 & 445.8 & 14.7 & 30.2 \\
\hline $\mathrm{LSD}_{0.05}$ for $(\mathrm{A})$ & $\mathrm{xB})$ & n.s. & n.s & n.s. & 46.9 & n.s. & n.s. \\
\hline \multirow{4}{*}{ Mean (B) } & Control & 2.8 & 4.1 & 35.5 & 345.2 & 14.0 & 25.7 \\
\hline & NPK & 4.2 & 5.9 & 38.3 & 423.3 & 14.6 & 29.4 \\
\hline & $\mathrm{NPK}+\mathrm{MgSO}_{4}$ & 4.5 & 6.0 & 38.9 & 424.6 & 14.9 & 30.2 \\
\hline & $\mathrm{NPK}+\mathrm{CaO}+\mathrm{MgO}$ & 4.9 & 6.4 & 40.3 & 450.2 & 14.6 & 31.6 \\
\hline $\mathrm{LSD}_{0.05}$ for $\mathrm{B}$ & & 0.3 & 0.3 & 1.5 & 21.2 & 0.7 & 2.0 \\
\hline WATER & & 3.9 & 5.1 & 37.3 & 397.3 & 14.0 & 29.0 \\
\hline INSOL PK & Mean (A) & 4.3 & 6.2 & 39.1 & 423.3 & 14.8 & 29.7 \\
\hline EKOSOL U & & 4.1 & 5.5 & 38.3 & 411.8 & 14.8 & 29.0 \\
\hline $\mathrm{LSD}_{0.05}$ for $\mathrm{A}$ & & 0.1 & 0.2 & 1.2 & 16.7 & 0.5 & n.s. \\
\hline
\end{tabular}

Table 2

Macronutrient content in winter wheat grain after application of foliar fertilizers under different soil fertilization conditions

\begin{tabular}{|c|c|c|c|c|c|c|c|}
\hline \multirow{2}{*}{$\begin{array}{l}\text { Foliar fertilizer } \\
\text { (A) }\end{array}$} & \multirow{2}{*}{$\begin{array}{l}\text { Soil fertilization } \\
\text { (B) }\end{array}$} & $\mathrm{N}$ & $\mathrm{P}$ & $\mathrm{K}$ & $\mathrm{Ca}$ & $\mathrm{Mg}$ & $\mathrm{S}$ \\
\hline & & \multicolumn{6}{|c|}{ [g kg-1 d.m.] } \\
\hline WATER & \multirow{3}{*}{ Control } & 17.40 & 2.66 & 4.54 & 0.53 & 1.11 & 0.66 \\
\hline INSOL PK & & 17.84 & 3.11 & 4.45 & 0.82 & 1.27 & 0.76 \\
\hline EKOSOL U & & 17.75 & 2.86 & 4.71 & 0.55 & 1.21 & 1.10 \\
\hline WATER & \multirow{3}{*}{ NPK } & 19.33 & 2.47 & 4.35 & 0.67 & 1.10 & 1.04 \\
\hline INSOL PK & & 20.21 & 2.56 & 4.18 & 0.79 & 1.14 & 0.88 \\
\hline EKOSOL U & & 21.91 & 2.77 & 3.94 & 0.55 & 1.17 & 1.23 \\
\hline WATER & \multirow{3}{*}{$\mathrm{NPK}+\mathrm{MgSO}_{4}$} & 18.38 & 2.41 & 4.33 & 0.51 & 1.12 & 1.09 \\
\hline INSOL PK & & 20.19 & 2.48 & 4.18 & 0.65 & 1.21 & 1.05 \\
\hline EKOSOL U & & 20.78 & 2.56 & 4.10 & 0.45 & 1.15 & 1.31 \\
\hline WATER & \multirow{3}{*}{$\mathrm{NPK}+\mathrm{CaO}+\mathrm{MgO}$} & 18.40 & 2.58 & 4.35 & 0.73 & 1.15 & 0.94 \\
\hline INSOL PK & & 21.65 & 2.82 & 4.14 & 0.87 & 1.28 & 1.00 \\
\hline EKOSOL U & & 20.75 & 2.86 & 5.15 & 0.61 & 1.24 & 1.06 \\
\hline $\operatorname{LSD}_{0.05}$ for $(\mathrm{AxB})$ & & n.s & 0.67 & 0.67 & n.s & n.s. & 0.20 \\
\hline \multirow{4}{*}{ Mean (B) } & Control & 17.66 & 2.62 & 4.56 & 0.70 & 1.20 & 0.84 \\
\hline & NPK & 20.48 & 2.60 & 4.15 & 0.68 & 1.14 & 1.05 \\
\hline & $\mathrm{NPK}+\mathrm{MgSO}_{4}$ & 19.78 & 2.48 & 4.21 & 0.73 & 1.16 & 1.15 \\
\hline & $\mathrm{NPK}+\mathrm{CaO}+\mathrm{MgO}$ & 20.27 & 2.75 & 4.54 & 0.85 & 1.23 & 1.00 \\
\hline $\mathrm{LSD}_{0.05}$ for B & & 1.45 & n.s & 0.30 & 0,07 & 0.09 & 0.09 \\
\hline WATER & \multirow{3}{*}{ Mean (A) } & 18.38 & 2.53 & 4.39 & 0.61 & 1.12 & 0.93 \\
\hline INSOL PK & & 19.97 & 2.75 & 4.24 & 0.78 & 1.22 & 0.92 \\
\hline EKOSOL U & & 20.30 & 2.57 & 4.48 & 0.54 & 1.19 & 1.17 \\
\hline $\mathrm{LSD}_{0.05}$ for $\mathrm{A}$ & & 1.14 & n.s & n.s. & 0.06 & 0.07 & 0.07 \\
\hline
\end{tabular}


Table 3

Macronutrient content in winter wheat straw after application of. foliar fertilizers under different soil fertilization conditions

\begin{tabular}{|c|c|c|c|c|c|c|c|}
\hline \multirow{2}{*}{$\begin{array}{l}\text { Foliar fertilizer } \\
\text { (A) }\end{array}$} & \multirow{2}{*}{$\begin{array}{l}\text { Soil fertilization } \\
\text { (B) }\end{array}$} & $\mathrm{N}$ & $\mathrm{P}$ & $\mathrm{K}$ & $\mathrm{Ca}$ & $\mathrm{Mg}$ & $\mathrm{S}$ \\
\hline & & \multicolumn{6}{|c|}{ [g kg-1 d.m.] } \\
\hline WATER & & 3.90 & 0.57 & 5.61 & 2.27 & 0.56 & 0.34 \\
\hline INSOL PK & Control & 5.58 & 0.56 & 5.81 & 2.62 & 0.82 & 0.39 \\
\hline EKOSOL U & & 4.30 & 0.56 & 6.05 & 2.30 & 0.72 & 0.41 \\
\hline WATER & & 4.76 & 0.54 & 6.33 & 2.36 & 0.65 & 0.52 \\
\hline INSOL PK & NPK & 5.34 & 0.76 & 6.02 & 3.04 & 0.81 & 0.41 \\
\hline EKOSOL U & & 6.59 & 0.61 & 6.20 & 2.39 & 0.85 & 0.37 \\
\hline WATER & & 4.39 & 0.55 & 6.57 & 2.22 & 0.66 & 0.70 \\
\hline INSOL PK & $\mathrm{NPK}+\mathrm{MgSO}_{4}$ & 5.63 & 0.55 & 6.58 & 2.64 & 0.80 & 0.79 \\
\hline EKOSOL U & & 5.75 & 0.53 & 6.15 & 2.33 & 0.82 & 0.80 \\
\hline WATER & & 4.76 & 0.63 & 6.70 & 2.36 & 0.92 & 0.45 \\
\hline INSOL PK & $\mathrm{NPK}+\mathrm{CaO}+\mathrm{MgO}$ & 6.36 & 0.64 & 6.90 & 3.10 & 0.92 & 0.57 \\
\hline EKOSOL U & & 7.32 & 0.82 & 6.84 & 2.80 & 1.13 & 0.50 \\
\hline $\mathrm{LSD}_{0.05}$ for $(\mathrm{AxB})$ & & 1.23 & 0.13 & n.s. & n.s. & 0.15 & 0.16 \\
\hline \multirow{4}{*}{ Mean (B) } & Control & 4.59 & 0.56 & 5.82 & 2.40 & 0.70 & 0.38 \\
\hline & NPK & 5.56 & 0.64 & 6.18 & 2.60 & 0.77 & 0.43 \\
\hline & $\mathrm{NPK}+\mathrm{MgSO}_{4}$ & 5.26 & 0.55 & 6.43 & 2.40 & 0.76 & 0.76 \\
\hline & $\mathrm{NPK}+\mathrm{CaO}+\mathrm{MgO}$ & 6.15 & 0.69 & 6.81 & 2.75 & 0.99 & 0.51 \\
\hline $\mathrm{LSD}_{0.05}$ for $\mathrm{B}$ & & 0.55 & 0.06 & 0.67 & 0.36 & 0.07 & 0.07 \\
\hline WATER & & 4.45 & 0.57 & 6.30 & 2.31 & 0.70 & 0.50 \\
\hline INSOL PK & Mean (A) & 5.73 & 0.63 & 6.32 & 2.85 & 0.84 & 0.54 \\
\hline EKOSOL U & & 5.99 & 0.63 & 6.31 & 2.45 & 0.88 & 0.52 \\
\hline $\mathrm{LSD}_{0.05}$ for $\mathrm{A}$ & & 0.44 & 0.05 & n.s. & 0.29 & 0.05 & n.s. \\
\hline
\end{tabular}

Table 4

Removal of macronutrients after application of foliar fertilizers of winter wheat under different soil fertilization conditions

\begin{tabular}{|c|c|c|c|c|c|c|c|}
\hline \multirow{2}{*}{$\begin{array}{l}\text { Foliar fertilizer } \\
\text { (A) }\end{array}$} & \multirow{2}{*}{$\begin{array}{l}\text { Soil fertilization } \\
\text { (B) }\end{array}$} & $\mathrm{N}$ & $\mathrm{P}$ & $\mathrm{K}$ & $\mathrm{Ca}$ & $\mathrm{Mg}$ & $\mathrm{S}$ \\
\hline & & \multicolumn{6}{|c|}{$\left[\mathrm{kg} \mathrm{ha}^{-1}\right]$} \\
\hline WATER & \multirow{3}{*}{ Control } & 57.54 & 9.18 & 29.42 & 15.35 & 4.61 & 5.66 \\
\hline INSOL PK & & 79.92 & 13.14 & 42.57 & 23.50 & 7.62 & 7.36 \\
\hline EKOSOL U & & 63.83 & 11.30 & 36.73 & 27.29 & 6.47 & 8.49 \\
\hline WATER & \multirow{3}{*}{ NPK } & 107.24 & 14.81 & 53.58 & 19.57 & 7.72 & 10.03 \\
\hline INSOL PK & & 117.39 & 17.91 & 58.64 & 32.50 & 9.36 & 11.72 \\
\hline EKOSOL U & & 130.84 & 16.68 & 54.48 & 33.42 & 9.58 & 11.18 \\
\hline WATER & \multirow{3}{*}{$\mathrm{NPK}+\mathrm{MgSO}_{4}$} & 104.65 & 14.88 & 56.11 & 20.37 & 8.33 & 15.80 \\
\hline INSOL PK & & 130.91 & 16.91 & 65.38 & 29.18 & 10.35 & 13.38 \\
\hline EKOSOL U & & 123.87 & 15.91 & 52.13 & 31.07 & 9.31 & 16.97 \\
\hline WATER & \multirow{3}{*}{$\mathrm{NPK}+\mathrm{CaO}+\mathrm{MgO}$} & 113.61 & 17.04 & 57.45 & 26.13 & 10.61 & 10.72 \\
\hline INSOL PK & & 180.43 & 20.62 & 71.99 & 55.85 & 12.66 & 11.69 \\
\hline EKOSOL U & & 149.56 & 20.56 & 66.98 & 35.94 & 13.25 & 10.36 \\
\hline $\mathrm{LSD}_{0.05}$ for $(\mathrm{AxB})$ & & 38.88 & 1.57 & 6.36 & 5,90 & 1.38 & 2.54 \\
\hline \multirow{4}{*}{ Mean (B) } & Control & 67.10 & 11.21 & 36.24 & 11.24 & 6.24 & 3.93 \\
\hline & NPK & 118.49 & 16.47 & 55.57 & 17.27 & 8.89 & 7.36 \\
\hline & $\mathrm{NPK}+\mathrm{MgSO}_{4}$ & 119.81 & 15.90 & 57.87 & 15.78 & 9.33 & 9.97 \\
\hline & $\mathrm{NPK}+\mathrm{CaO}+\mathrm{MgO}$ & 147.86 & 19.41 & 65.47 & 20.36 & 12.17 & 8.70 \\
\hline $\mathrm{LSD}_{0.05}$ for B & & 17.45 & 0.70 & 2.85 & 1.15 & 0.62 & 0.38 \\
\hline WATER & \multirow{3}{*}{ Mean (A) } & 95.76 & 13.98 & 49.14 & 13.93 & 7.82 & 6.89 \\
\hline INSOL PK & & 127.16 & 17.14 & 59.64 & 19.50 & 9.99 & 7.80 \\
\hline EKOSOL U & & 117.02 & 16.11 & 52.58 & 15.06 & 9.65 & 7.99 \\
\hline $\mathrm{LSD}_{0.05}$ for $\mathrm{A}$ & & 13.74 & 0.55 & 2.25 & 0.90 & 0.49 & 0.30 \\
\hline
\end{tabular}


Table 5

Quality parameters of winter wheat after application of foliar fertilizers under different soil fertilization conditions

\begin{tabular}{|c|c|c|c|c|c|}
\hline \multirow{2}{*}{$\begin{array}{l}\text { Foliar fertilizer } \\
\text { (A) }\end{array}$} & \multirow{2}{*}{$\begin{array}{l}\text { Soil fertilization } \\
\text { (B) }\end{array}$} & Total protein $(\mathrm{N} \times 5.7)$ & Protein yield & \multirow{2}{*}{$\begin{array}{l}\text { Gluten content } \\
{[\% \text { d.m. }]}\end{array}$} & \multirow{2}{*}{$\begin{array}{c}\text { Gluten weakening } \\
{[\mathrm{mm}]}\end{array}$} \\
\hline & & {$\left[\mathrm{g} \mathrm{kg}^{-1}\right.$ d.m. $]$} & {$\left[\mathrm{kg} \mathrm{ha}^{-1}\right]$} & & \\
\hline WATER & \multirow{3}{*}{ Control } & 99.18 & 289.88 & 19.56 & 6.56 \\
\hline INSOL PK & & 101.69 & 353.69 & 21.22 & 7.89 \\
\hline EKOSOL U & & 101.16 & 335.95 & 19.89 & 8.33 \\
\hline WATER & \multirow{3}{*}{ NPK } & 110.20 & 462.20 & 21.33 & 7.44 \\
\hline INSOL PK & & 115.10 & 537.62 & 23.67 & 9.11 \\
\hline EKOSOL U & & 124.89 & 518.31 & 22.44 & 10.11 \\
\hline WATER & \multirow{3}{*}{$\mathrm{NPK}+\mathrm{MgSO}_{4}$} & 104.79 & 489.95 & 22.67 & 9.67 \\
\hline INSOL PK & & 115.10 & 568.85 & 24.33 & 9.67 \\
\hline EKOSOL U & & 118.43 & 545.36 & 26.11 & 10.44 \\
\hline WATER & \multirow{3}{*}{$\mathrm{NPK}+\mathrm{CaO}+\mathrm{MgO}$} & 104.88 & 551.48 & 24.44 & 10.56 \\
\hline INSOL PK & & 123.41 & 585.04 & 28.11 & 11.33 \\
\hline EKOSOL U & & 118.26 & 605.87 & 30.44 & 11.56 \\
\hline $\mathrm{LSD}_{0.05}$ for $(\mathrm{AxB})$ & & n.s. & n.s. & 2.76 & n.s. \\
\hline \multirow{4}{*}{ Mean (B) } & Control & 100.67 & 277.17 & 20.22 & 7.59 \\
\hline & NPK & 116.75 & 498.67 & 22.48 & 8.89 \\
\hline & $\mathrm{NPK}+\mathrm{MgSO}_{4}$ & 112.77 & 508.05 & 24.37 & 9.93 \\
\hline & $\mathrm{NPK}+\mathrm{CaO}+\mathrm{MgO}$ & 115.51 & 575.80 & 27.67 & 11.15 \\
\hline $\mathrm{LSD}_{0.05}$ for B & & 8.29 & 54.55 & 1.24 & 0.83 \\
\hline WATER & \multirow{3}{*}{ Mean (A) } & 104.76 & 413.19 & 22.00 & 8.56 \\
\hline INSOL PK & & 113.84 & 499.25 & 24.33 & 9.50 \\
\hline EKOSOL U & & 115.68 & 482.40 & 24.72 & 10.11 \\
\hline $\mathrm{LSD}_{0.05}$ for $\mathrm{A}$ & & 6.53 & 42.95 & 0.97 & 0.66 \\
\hline
\end{tabular}

Table 6

Relationships between elements in winter wheat grain and straw after application of foliar fertilizers under different soil fertilization conditions

\begin{tabular}{|c|c|c|c|c|c|}
\hline $\begin{array}{l}\text { Foliar fertilizer } \\
\text { (A) }\end{array}$ & $\begin{array}{l}\text { Soil fertilization } \\
\text { (B) }\end{array}$ & $\begin{array}{c}\mathrm{K}:(\mathrm{Ca}+\mathrm{Mg}) \\
\quad \text { in grain }\end{array}$ & $\begin{array}{l}\mathrm{K}:(\mathrm{Ca}+\mathrm{Mg}) \\
\quad \text { in straw }\end{array}$ & $\mathrm{N} / \mathrm{S}$ in grain & $\mathrm{N} / \mathrm{S}$ in straw \\
\hline WATER & \multirow{3}{*}{ Control } & 1.0 & 0.9 & 26.4 & 11.5 \\
\hline INSOL PK & & 0.8 & 0.8 & 23.5 & 14.3 \\
\hline EKOSOL U & & 1.0 & 0.9 & 16.1 & 10.5 \\
\hline WATER & \multirow{3}{*}{ NPK } & 0.9 & 1.0 & 18.6 & 9.2 \\
\hline INSOL PK & & 0.8 & 0.7 & 23.0 & 13.0 \\
\hline EKOSOL U & & 0.8 & 0.8 & 17.8 & 17.8 \\
\hline WATER & \multirow{3}{*}{$\mathrm{NPK}+\mathrm{MgSO}_{4}$} & 0.9 & 1.0 & 16.9 & 6.3 \\
\hline INSOL PK & & 0.8 & 0.9 & 19.2 & 7.1 \\
\hline EKOSOL U & & 0.9 & 0.9 & 15.9 & 7.2 \\
\hline WATER & \multirow{3}{*}{$\mathrm{NPK}+\mathrm{CaO}+\mathrm{MgO}$} & 0.9 & 0.9 & 19.6 & 10.6 \\
\hline INSOL PK & & 0.7 & 0.8 & 21.7 & 11.1 \\
\hline EKOSOL U & & 1.0 & 0.8 & 19.6 & 14.6 \\
\hline Mean & & 0.9 & 0.9 & 19.5 & 11.1 \\
\hline \multirow{4}{*}{ Mean (B) } & Control & 0.9 & 0.8 & 21.0 & 12.1 \\
\hline & NPK & 0.8 & 0.8 & 19.5 & 12.9 \\
\hline & $\mathrm{NPK}+\mathrm{MgSO}_{4}$ & 0.8 & 0.9 & 17.2 & 6.9 \\
\hline & $\mathrm{NPK}+\mathrm{CaO}+\mathrm{MgO}$ & 0.8 & 0.8 & 20.3 & 12.1 \\
\hline Mean & & 0.8 & 0.8 & 19.5 & 11.0 \\
\hline WATER & \multirow{3}{*}{ Mean (A) } & 0.9 & 0.9 & 19.8 & 8.9 \\
\hline INSOL PK & & 0.8 & 0.8 & 21.7 & 10.6 \\
\hline EKOSOL U & & 0.9 & 0.8 & 17.4 & 11.5 \\
\hline Mean & & 0.9 & 0.8 & 19.6 & 10.3 \\
\hline
\end{tabular}




\section{DISCUSSION}

\section{Yield potential}

Wheat represents plants that are sensitive to acidic soil, and therefore it produced the highest yields in the $\mathrm{CaO}+\mathrm{MgO}$ fertilization treatment. Numerous studies carried out on this research problem have confirmed this finding [13-16]. The application of the deacidifying fertilizer had a beneficial impact on all the winter wheat yield components, as it limited the presence of mobile aluminium in the soil to a level of 28 $\mathrm{mg} \mathrm{Al} \mathrm{kg}{ }^{-1}$ in comparison with the amount of $140 \mathrm{mg}$ $\mathrm{Al} \mathrm{kg}{ }^{-1}$ in the other soil fertilization treatments [17]. The introduction of sulphur and magnesium to the soil without changing the $\mathrm{pH}$ value did not induce significant changes in the yields of winter wheat compared with the basic NPK treatment, as demonstrated by $\mathrm{E} \mathrm{a} \mathrm{b} \mathrm{u} \mathrm{d} \mathrm{a} \mathrm{et} \mathrm{al.} \mathrm{[18]} \mathrm{in} \mathrm{their} \mathrm{investigations} \mathrm{of} \mathrm{oats.} \mathrm{The}$ different response of these cereals to the application of magnesium sulphate is related to the higher tolerance of oats to acidic soil $\mathrm{pH}$ than that of wheat. Foliar feeding increased the grain yield, but to a lesser extent than soil fertilization, since it had no effect on the number of grains per ear. Although a great number of studies have indicated a beneficial impact of foliar application of nutrients [19-23], there are also reports on the absence of plant response to foliar feeding [24, 25].

\section{The mineral composition}

The content of the analysed macronutrients in winter wheat grain and straw depended on the type of soil fertilization applied; only the phosphorus content in the grain was similar in all the soil fertilization treatments. Soil liming applied as a basic deacidification treatment increased nutrient use and resulted in higher soil bioactivity $[18,26]$. The highest nitrogen content in the grain and straw in this fertilization treatment may have been related to the higher mineralisation rate and the enhanced activity of nitrifying bacteria. The higher content of phosphorus resulted from limited chemical sorption of the nutrient in soil [27], whereas calcium and magnesium were supplied with the deacidifying fertilizer.

The application of $\mathrm{MgSO}_{4}$ in the fertilization treatment increased the content of sulphur and magnesium, but reduced the amount of phosphorus in winter wheat grain and straw, which may suggest phosphate binding to $\mathrm{Mg}^{2+}$ ions in sparingly soluble forms at the stage of application of the fertilizers, as they were used in the same period. There are literature reports that show lower phosphorus content in plants resulting from sulphur fertilization [26, 28].

Foliar feeding caused an increase in the content of $\mathrm{N}, \mathrm{Ca}$, and $\mathrm{Mg}$ in winter wheat grain and straw. However, the differences should be attributed to the increased uptake and utilisation of soil nutrients result- ing from the application of the foliar fertilizers rather than to the direct effects of nutrient supply with these fertilizers [4]. M i chałe k et al. [23, 29] report that the higher nutrient uptake from soil induced by foliar feeding is related to enhanced photosynthesis, transpiration, and plant respiration [30-32].

The soil fertilization treatment had a greater effect on nutrient removal than foliar feeding. In the $\mathrm{NPK}+\mathrm{CaO}+\mathrm{MgO}$ treatment, $\mathrm{N}, \mathrm{P}, \mathrm{K}, \mathrm{Ca}$, and $\mathrm{Mg}$ exhibited the highest values of removal, since the reduction in the amount of mobile aluminium maintains the plant root system in full efficiency [34]. In turn, the greatest sulphur removal in the $\mathrm{MgSO}_{4}$ fertilization treatment resulted from the low abundance of absorbable forms of this nutrient in the soil.

\section{Yield quality parameters}

The experimental factors applied had a similar impact on the protein content in winter wheat grain. However, the soil fertilization treatments exerted a greater effect on the protein yield than the foliar fertilizers. The beneficial impact of soil fertilization on the protein content and yield was associated with the nitrogen rate $[34,35]$. In turn, the increased content of protein and gluten in the foliar feeding treatment may have resulted from nutrient supply in the critical periods of increased demand when nutrient uptake by the root system did not cover the nutritional requirements of wheat $[11,36]$. The quality of gluten was correlated with its content, since the higher content was accompanied by higher weakening, i.e. worse gluten quality. The results obtained are in agreement with the findings reported by $\mathrm{Mak}$ a rewicz et al. [37]. A favourable effect of foliar fertilizers on wheat quality parameters has also been demonstrated in other papers [4, 3, 22, 38].

The values of the calculated nutrient ratios in the conducted experiment were similar, but a narrower $\mathrm{N}: \mathrm{S}$ ratio in winter wheat grain and straw was only obtained in the treatment with sulphur addition. The $\mathrm{K} /(\mathrm{Ca}+\mathrm{Mg})$ and $\mathrm{N}: \mathrm{S}$ ratios were different from the optimal ranges; only the $\mathrm{N}: \mathrm{S}$ ratio in the grain fertilized with sulphur addition was most similar to $15: 1$, regarded as an optimal value [39-41], and indicated a low soil sulphur level [42]. The $\mathrm{K} /(\mathrm{Ca}+\mathrm{Mg})$ ratio values that were lower than the optimum $1.6-2.1: 1$ resulted from the low content of available potassium in the soil, which led to non-exchangeable binding of part of the potassium supply introduced into the soil with the fertilizers.

\section{CONCLUSIONS}

1. In comparison with foliar feeding, soil fertilization exerted a more substantial effect on winter wheat yield, individual yield components, and macronutrient content in the grain and straw. 
2. Foliar feeding had a positive impact on the quality parameters of winter wheat. EKOSOL U was more efficient due to the content of micronutrients in its elemental composition, whereas INSOL PK had a greater effect on yield.

3. Foliar feeding and soil fertilization increased micronutrient removal. The highest values of $\mathrm{N}, \mathrm{P}, \mathrm{K}$, $\mathrm{Ca}$, and $\mathrm{Mg}$ removal were obtained after application of INSOL PK and NPK $+\mathrm{CaO}+\mathrm{MgO}$. The application of magnesium sulphate in the fertilization treatment resulted in higher sulphur removal and a narrower $\mathrm{N}: \mathrm{S}$ ratio in winter wheat grain and straw.

4. The best yield quantity and quality parameters were obtained in the $\mathrm{NPK}+\mathrm{CaO}+\mathrm{MgO}$ soil fertilization treatment; INSOL PK and EKOSOL U exhibited similar effects.

\section{Acknowledgements}

This research was supported by the Ministry of Science and Higher Education of Poland as part of the statutory activities of the Department of Agricultural and Environmental Chemistry, University of Life Sciences in Lublin.

\section{REFERENCES}

1. Brogowski Z, Czarnowska K. Stan jonowy pszenicy ozimej na tle wzrastającego nawożenia azotowego. Rocz Nauk Rol., A, 1987; 106(4): 35-50.

2. Chwil S. Ocena skutków nawożenia pszenicy ozimej [Evaluation of nitrogen fertilization of winter wheat]. Fragm. Agron. 2004; 21, 1(81): 19-28.

3. Wojcieska-Wyskupajtys U. Międzynarodowe Sympozjum „Dolistne nawożenie - metoda zwiększania produkcji i zmniejszenia skażenia środowiska”. Fragm Agron. 1996; 4(52): 115-122.

4. Chwil S. The effect of magnesium and nitrogen on the quality parameters of winter wheat yield. Ann Univ Mariae Curie-Skłodowska, E Agric. 2009; 64(2): 61-66.

5. Jaskulska I. Wpływ dolistnego stosowania makroi mikroelementów na wielkośći jakość plonów pszenicy ozimej i buraka cukrowego [Effect of hte foliar application of macro- and microelements on the winter wheat and sugar beet yielding and yield quality]. Zesz Probl Post Nauk Rol. 2010; 556: 119-126.

6. Skiba T. Wstępne obserwacje nad dolistnym stosowaniem mocznika na zbożaw doświadczeniu wazonowym. Materiały Seminarium Naukowego „Dolistne dokarmianie i ochrona roślin w świetle badań i doświadczeń praktyki rolniczej" Puławy, 13-14 grudnia. 1988: 57-75.

7. Ko c oń A. Efektywność wykorzystania azotu z mocznika stosowanego dolistniei doglebowo przez pszenicę ozimą i bobik [Effect of nitrogen utilization from urea $\left({ }^{15} \mathrm{~N}\right)$ applied in-leaves or in-soil by winter wheat and faba bean]. Acta Agroph. 2003; 85: 55-63.
8. Hoytova D. A review of foliar fertilization of some vegetables crops. Ann Re Res Biol. 2013; 3(4): 455-465.

9. Jaskulski D. Porównanie wpływu dolistnego stosowania nawozów na efekty produkcyjne oraz ekonomiczne uprawy niektórych roślin polowych [Comparison of the effect of foliar fertilization fertilizers on economic and production effects of growing same field crops]. Fragm Agron. 2007; 1(79): 106-112.

10. Drzewiecki S, Pietryga J. Wpływ łącznego stosowania regulatora wzrostu Terpal C 460 SL z nawozami dolistnymi na cechy jakościowe ziarna pszenicy ozimej. Prog Plant Prot. 2003; 43(2): 595-597.

11.Szewczuk C, Michałojć Z. Praktyczne aspekty dolistnego dokarmiania roślin [Practical aspect of foliar fertilization]. Acta Agroph. 2003; 85: 19-29.

12. Nowosielski O. Metody oznaczania potrzeb nawożenia. PWRiL, Warszawa 1974.

13. Moskal S., Mercik S. Długotrwałość wpływu wapnowania na odczyn glebi plonowanie roślin. Mat. Symp. „Wapnowanie jako czynnik wzrostu urodzajności gleb”. IUNG Puławy 1983, 77-82.

14. Żądełek J. Wpływ wieloletniego wapnowania i nawożenia mineralnego na plonowanie pszenicy ozimej i zmiany właściwości chemicznych gleby lekkiej, Mat. Symp. „Wapnowanie jako czynnik wzrostu urodzajności gleb”. IUNG Puławy 1983: 159-162.

15. Kalembasa S., Żądełek J. Wpływ wapnowania i nawożenia azotem na plon żyta, pszenicy i pszenżyta [The influence of limining and nitrogen fertilization on the field of Winter rye, winter wheat and triticale]. Zesz Probl Postęp Nauk Roln. 1998; 456: 269-272.

16. Hołubowicz-Kliza G. Wapnowanie gleb w Polsce. JUNG - PIB, Puławy 2006.

17. Chwil S. Changes of basic indices of acidification in soil profile as affected by fertilization. Zesz Probl Post Nauk Rol. 2002;. 482: 79-85.

18. Łabuda S, Filipek T, Dechnik I. Reakcja owsa na zróżnicowane formy wapniai magnezu w doświadczeniu modelowym. Rocz Glebozn. 1992; 43: 29-35.

19. Chwil S. Plonowanie pszenicy ozimej pod wpływem dolistnego dokarmiania wieloskładnikowym nawozem Wuxal top $\mathrm{N}$ w warunkach zróżnicowanego nawożenia azotem [Field of Winter wheat as infuenced by foliar application of Wuxal Top $\mathrm{N}$ dunder conditions of different nitrogen fertilization of soil]. Rocz Glebozn. 2000; 51(3/4): 129-134.

20. Chwil S, Szewczuk Cz. Wpływ dolistnego dokarmiania buraka cukrowego na jego plon i niektóre cechy jakościowe [Influence of sugar beet foliale fading on field and some qualitative traits]. Acta Agrophys. 2003; 85: 117124.

21. Tobiasz-Salach R, Bobrecka-Jarmo D. Wpływ wieloskładnikowych nawozów dolistnych na plonowanie i skład chemiczny owsa [Influence of multicomponenet foliar of fertilizer on the chemical crop and field composition of oats]. Acta Agrophys. 2003; 85: 89-98. 
22. Kulczycki G, Januszkiewicz R, Jachym$\mathrm{czak}$ A. The effect of foliar applied fertilizer ekolist on the yield and chemical composition of spring wheat. Zesz. Nauk. UP Wroc., Rol., 2009; XCV, 574: 19-28.

23. Michałek S, Chwil S, Pranagal J, Ligęza S. Wczesny wzrost kukurydzy w warunkach dolistnego dokarmiania nawozami Violo [Maize early growth under conditions of foliar nutrition with Viflo fertilizers]. Zesz Probl Post Nauk Rol, 2009; 542: 333-339.

24. Kruczek A. Effect of the method and term of foliar nutrition with urea solution anda multiple fertilizer on nitrogen and dry mass content in maize. Acta Agrophys. 2003; 85: 65-76. DOI: http://dx.doi.org/10.5586/aa.2014.017.

25. Tobiasz-Salach R, Bobrecka-Jamro D, Szpunar-Krok E. Wpływ dolistnego dokarmiania na plon i skład chemiczny ziarna owsa. Biuletyn Instytutu Hodowli i Aklimatyzacji Roślin 2007; 246: 55-60.

26. Kozłowska J. Bezpośredni i następczy wpływ nawożenia siarką i wapnowania na zmiany w składzie jonowym roślin. Chem Inż Ekol. 2000; 7(6): 575-591.

27. Tkaczyk P, Chwil S. Formy i frakcje fosforu mineralnego w glebie nawożonej nawozami mineralnymi i obornikiem. Ann Univ Mariae Curie-Skłodowska, E Agric. 2004; 59(4): 1723-1730.

28. Podleśna A. Wpływ nawożenia siarka na zawartość i pobranie składników pokarmowych przez rzepak ozimy [The effect of sulfur fertilization on concentration and uptake of nutrients by winter oilseed rape]. Rośliny oleiste. 2004; 25: 627-636.

29. Michałek S, Chwil S, Pranagal J, Ligęza S. Wpływ dolistnych nawozów Viflo na wymianę gazową liści, fluorescencję oraz początkowy wzrost bobu (Vica faba L. odm. Maior) [Effect of VIFLO foliar fertilizers on the leaf gas exchange, fluorescence and early growth of broad bean (Vicia faba L. cv. Maior)]. Zesz Probl Post Nauk Rol. 2009; 542: 341-148.

30.Hopmans JW, Bristow KL. Current capabilities and future needs of root water and nutrient uptake modeling. Adv Agron. 2002; 77: 103-183. http://dx.doi.org/10.1016/ S0065-2113(02)77014-4

31. Chavarria G, Santos HP. Plant Water Relations: Absorption, Transport and Control Mechanisms. In: Montanaro G, Dichio B (eds.) Advances in Selected Plant Physiology Aspects. Rijeka: InTech. 2012: 105-132. http:// dx.doi.org/10.5772/33478

32. Chwil S. A study on the effects of foliar feeding under different soil fertilization conditions on the yield structure and quality of common oat (Avena sativa L.). Acta Agrobot. 2014; 67(1): 109-120. DOI: http://dx.doi.org/10.5586/ aa.2014.017

33. Bednarek W, Lipiński W. Oddziaływanie nawożenia mineralnego i wapnowania na fizyko-chemiczne właściwości gleby lekkiej, plonowanie oraz niektóre cechy jęczmienia jarego [Influence of mineral fertilization and liming on physico-chemical properties of light soil, crop yield and some features of spring barley]. Rocz Gleb. 1996; 47, 3/4, 109-115.
34. Stanowski S, Podolska G, Pacewicz K. Wpływ nawożenia azotem na plonowanie i jakość ziarna odmian pszenicy ozimej. Ann Univ Mariae Curie-Skłodowska, E Agric. 2004; 59(3): 1363-1369.

35.Podolska G, Stankowski S, Dworakowski T. Wpływ dawki nawożenia azotem na wielkość plonu i wartość technologiczną ziarna pszenicy ozimej. Fragm Agron. 2007; 2(94): 274-282.

36. Ja skulski D, J a sk u lska I. Efekt produkcyjny dolistnego stosowania nawozu magnezowo-mikroelementowego Sonata zboże w uprawie pszenicy ozimej w zależności od ilości opadów i zasobności gleby [Production effect of foliar application of magnesium-and-microelement fertilizer sonata zboże on the cultivation of winter wheat depending on the rainfall and soil richness]. Zesz Probl Post Nauk Rol. 2009; 541: 157-164.

37. Makarewicz A, Gąsiorowska B, Cybulska A. Wpływ dolistnego nawożenia azotem na wybrane parametry jakościowe ziarna pszenicy ozimej [The effect of foliar nitrogen fertilization on the selected quality parameters of winter wheat grain]. Fragm Agron. 2012; 29(1): 105-113.

38.Jaskulski D, Piekarczyk M, Jaskulska I. Wpływ nawożenia dolistnego Makro- i mikroelementami na plon i jakość technologiczną ziarna pszenicy ozimej uprawianej w krótkotrwałej monokulturze [Effect of foliar nutrition with macro- and microelements on the yield and technological quality of winter wheat grain cultivated in short-time monoculture]. Zesz Probl Post Nauk Rol. 2011; 559: 97-104.

39. Griffiths MW, Kettlewell PS, Hocking TJ. Effects of foliar-applied sulphur and nitrogen on grain growth, grain sulphur and nitrogen concentrations and yield of winter wheat. J Agricult Sci Cambridge. 1995; 125: 331339. http://dx.doi.org/10.1017/S0021859600084835

40. Hussain Z, Leitch MH. The effect of applied sulphur on the growth, grain yield and control of powdery mildew in spring wheat. Ann Appl Biol. 2005; 147: 49-56. http://dx.doi.org/10.1111/j.1744-7348.2005.00007.x

41. Kaczor A, Zuzańska J. Znaczenie siarki w rolnictwie [Importance of sulphur in agriculture]. Chemia. Dydaktyka. Ekologia. Metrologia. 2009; 14(1-2): 69-78.

42.Eriksen J, Nielsen M, Mortensen JV, Schjorring JK. Redistribution of sulphur during generative growth of barley plants with different sulphur and nitrogen status. Plant Soil. 2001; 230: 239-246. http://dx.doi. org/10.1023/A:1010328115203 
Oddziaływanie dolistnego dokarmiania w warunkach zróżnicowanego nawożenia doglebowego na strukturę plonu i jakość pszenicy ozimej (Triticum aestivum L.)

\section{Streszczenie}

Celem przeprowadzonych badań była analiza dolistnego dokarmiania pszenicy ozimej odmiany 'Kobra' na zróżnicowanych wariantach nawożenia doglebowego związkami wapnia i magnezu. Nawozy dolistne INSOL PK + 5\% roztwór mocznika i EKOSOL U stosowano 3-krotnie w okresie wegetacji na czterech wariantach nawożenia doglebowego: kontrola bez nawożenia, NPK, NPK $+\mathrm{MgSO}_{4} \cdot 7 \mathrm{H}_{2} \mathrm{O}, \mathrm{NPK}+\mathrm{CaO}$ $+\mathrm{MgO}$. Badania prowadzono $\mathrm{w}$ oparciu o trzyletnie doświadczenie polowe, na glebie średniej o $\mathrm{pH}$ 4,2 w $1 \mathrm{~mol} \mathrm{KCl} \cdot \mathrm{dm}^{-3}$ i składzie granulometrycznym pyłu gliniastego. Gleba charakteryzowała się niską zawartością fosforu i potasu przyswajalnego oraz bardzo niską zawartością siarki i magnezu. Stosowane nawozy dolistne i warianty nawożenia doglebowego różnicowały wskaźniki plonowania, zawartość makroelementów w ziarnie i słomie oraz zawartość i jakość glutenu. $\mathrm{Z}$ zastosowanych wariantów nawożenia doglebowego najlepsze efekty produkcyjne i parametry jakościowe w uprawie pszenicy ozimej uzyskano z udziałem wapna magnezowego $\mathrm{w}$ dawce według pojedynczej kwasowości hydrolitycznej. Nawozy dolistne w większym stopniu oddziaływały na plonowanie i zawartość glutenu niż skład mineralny ziarna i słomy pszenicy ozimej.

Handling Editor: Elżbieta Weryszko-Chmielewska

This is an Open Access digital version of the article distributed under the terms of the Creative Commons Attribution 3.0 License (creativecommons.org/licenses/by/3.0/), which permits redistribution, commercial and non-commercial, provided that the article is properly cited.

(CThe Author(s) 2014 Published by Polish Botanical Society 